\title{
Age-related hearing loss: biological aspects
}

\author{
E Cassandro*, G Chiarella \\ From de Senectute: Age and Health Forum \\ Catanzaro, Italy. 5-7 December 2009
}

Presbycusis is one of the more prevalent neurodegenerative disease of aging. There are many studies about the influence of environmental and genetic factors. Agerelated hearing loss is caused by changes in peripheral (cell loss in organ of Corti, spiral ganglion and stria vascularis) and central auditory systems (consequent to peripheral modifications or for changes in the neurobiologic activity underlying central processing of auditory informations) [1]. Consequences are reduced sensitivity, tuning sharpness, compression, and reduced signal-tonoise ratios, deficits in auditory discrimination, temporal processing, processing of degraded auditory signals or when embedded in competing acoustic signals. Approaching biology of age-related hearing loss is complex: it needs to clarify some peripheral aspects with different cochlear structure and cellular type affected, and some others central auditory processing aspects. There are some peripherally induced central effects and others direct neurodegenerative changes in the brain. Moreover biochemical and mechanical injury in life course can represent a risk factor for auditory function particularly for organ of Corti. This complicates the attempt of separate pure presbycusis from socioacusis. Research indicated some "longevity genes" and longevity-promoting life-styles (obesity and correlated conditions like hyperlipidemia, hypercholesterolemia, hypertension, hyperhomocysteinemia and cardiovascular disease, smoking, diet and diabetes [2,3]. Age-related hearing loss seems to occur more frequently in industrial population than in non-industrial [4]. The relation between alleles pro or against-aging and environment maybe play a determinant role in the evolution of hearing with aging. Until such genes are identified, the best strategy is to reduce

\footnotetext{
"Magna Graecia" University, Catanzaro, Italy, Experimental and Clinical Medicine Department, Audiology and Phoniatrics Chair, Regional Center for Cochlear Implants and ENT Diseases

Full list of author information is available at the end of the article
}

environmental risk factors (noise exposure, ototoxic drugs, industrial solvents or combinations of these).

Published: 27 August 2010

\section{References}

1. Ohlemiller KK, Frisina RD: Age-Related Hearing Loss and Its Cellular and Molecular Bases. Auditory Trauma, Protection, and Repair Springer USSchacht J, Popper AN, Fay RR 2008.

2. Harper JM, Salmon $A B$, Chang $Y$, et al: Stress resistance and aging: influence of genes and nutrition. Mech Ageing Dev 2006, 127:687-694.

3. Karasik D, Demissie S, Cupples AL, Kiel DP: Disentangling the genetic determinants of human aging: biological age as an alternative to the use of survival measures. J Gerontol Biol Sci 2005, 60A:574-587.

4. Rosen S, Bergman M, Plester D, et al: Presbycusis study of a relatively noise-free population in the Sudan. Ann Otol Rhinol Laryngol 1962, 71:727-742.

doi:10.1186/1471-2318-10-S1-L82

Cite this article as: Cassandro and Chiarella: Age-related hearing loss: biological aspects. BMC Geriatrics 2010 10(Suppl 1):L82.

\section{Submit your next manuscript to BioMed Central and take full advantage of: \\ - Convenient online submission \\ - Thorough peer review \\ - No space constraints or color figure charges \\ - Immediate publication on acceptance \\ - Inclusion in PubMed, CAS, Scopus and Google Scholar \\ - Research which is freely available for redistribution \\ Submit your manuscript at www.biomedcentral.com/submit}

